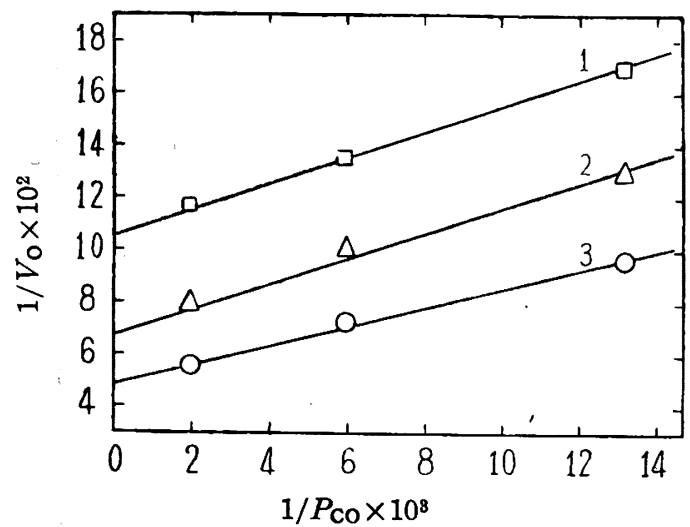

$\mathrm{V}_{2} \mathrm{O}_{5}-\alpha-\mathrm{Al}_{2} \mathrm{O}_{3}(1 \mathrm{~mol} \%) 0.2 \mathrm{~g}$, 流速 $62.7 \mathrm{cc} / \mathrm{min}$, $P_{\mathrm{O}_{2}}=121 \mathrm{~mm} \mathrm{Hg}$,

$\square: 425^{\circ} \mathrm{C}, \triangle: 450^{\circ} \mathrm{C}, \bigcirc: 475^{\circ} \mathrm{C}$

図 $6 \mathrm{~V}_{2} \mathrm{O}_{5}-\alpha-\mathrm{Al}_{2} \mathrm{O}_{3}(1 \mathrm{~mol} \%)$ 触媒による $\mathrm{CO}$ 酸化 $1 / V_{\mathrm{O}} \sim 1 / P_{\text {Co }}$ の plot

表 $5 \mathrm{~V}_{2} \mathrm{O}_{5}-\mathrm{MoO}_{3}(1 \mathrm{~mol} \%), \mathrm{V}_{2} \mathrm{O}_{5}-\alpha-\mathrm{Al}_{2} \mathrm{O}_{3}(1 \mathrm{~mol} \%)$ 触媒に対する $k^{\prime}, K_{\mathrm{CO}}, k$ の值

$\begin{array}{ccccc}\text { 触 媒 } & \begin{array}{c}\text { 温度 } \\ \left({ }^{\circ} \mathrm{C}\right)\end{array} & k^{\prime} & \begin{array}{c}K_{\mathrm{CO}} \\ (1 / \mathrm{mm} \mathrm{Hg})\end{array} & k\left(\frac{\mathrm{cc}}{\mathrm{g} \cdot \mathrm{min}}\right) \\ \mathrm{V}_{2} \mathrm{O}_{5}-\mathrm{MoO}_{3} & 390 & 6.05 & 1.28 \times 10^{-2} & 12.9 \\ & 415 & 10.5 & 1.01 \times 10^{-2} & 25.2 \\ & 440 & 16.9 & 8.00 \times 10^{-3} & 45.6 \\ \mathrm{~V}_{2} \mathrm{O}_{5}-\alpha-\mathrm{Al}_{2} \mathrm{O}_{3} & 425 & 9.82 & 1.98 \times 10^{-2} & 32.5 \\ & 450 & 15.3 & 1.35 \times 10^{-2} & 62.3 \\ & 475 & 23.6 & 9.62 \times 10^{-3} & 118\end{array}$

$\mathrm{V}_{2} \mathrm{O}_{5}-\mathrm{MoO}_{3}(1 \mathrm{~mol} \%)$;

$K_{\mathrm{CO}}=1.87 \times 10^{-5} \mathrm{e}^{8600 / R T}(1 / \mathrm{mmHg})$,

$q_{\mathrm{cO}}=8.60 \mathrm{kcal} / \mathrm{mol}$

$\mathrm{V}_{2} \mathrm{O}_{5}-\alpha-\mathrm{Al}_{2} \mathrm{O}_{3}(1 \mathrm{~mol} \%)$;

$K_{\mathrm{CO}}=3.19 \times 10^{-7} \mathrm{e}^{15300 / R T}(1 / \mathrm{mm} \mathrm{Hg})$,

$q_{\mathrm{co}}=15.3 \mathrm{kcal} / \mathrm{mol}$

の関係式がえられる。

一方 $\mathrm{V}_{2} \mathrm{O}_{5}-\mathrm{MoO}_{3}(1 \mathrm{~mol} \%), \mathrm{V}_{2} \mathrm{O}_{5}-\alpha-\mathrm{Al}_{2} \mathrm{O}_{3}(1 \mathrm{~mol} \%)$ 触媒に 対する酸素の吸着平衝定数 $K_{0}$ はさきの吸着実験加ら表 2 に与え られており, この值と $k^{\prime}$ の值から表面反応速度定数 $k$, 活性化熱 $E$ がつぎのように算出される。

$$
\begin{aligned}
\mathrm{V}_{2} \mathrm{O}_{5} & -\mathrm{MoO}_{3}(1 \mathrm{~mol} \%) ; \\
k & =3.33 \times 10^{8} \mathrm{e}^{-22400 / R T}(\mathrm{cc} / \mathrm{g} \cdot \mathrm{min}), \\
E & =22.4 \mathrm{kcal} / \mathrm{mol} \\
\mathrm{V}_{2} \mathrm{O}_{5}-\alpha-\mathrm{Al}_{2} \mathrm{O}_{3}(1 \mathrm{~mol} \%) ; & \\
k & =4.94 \times 10^{9} \mathrm{e}^{-26100 / R T}(\mathrm{cc} / \mathrm{g} \cdot \mathrm{min}), \\
E & =26.1 \mathrm{kcal} / \mathrm{mol}
\end{aligned}
$$

このようにして求められた $q_{\mathrm{O}}, q_{\mathrm{co}}, K_{\mathrm{O}}, K_{\mathrm{Co}}$ の值を用いて $\left(12^{\prime}\right)$ 式により一酸化炭素酸化の見かけの活性化熱 $E_{\mathrm{A}}$ を計算し

\begin{tabular}{|c|c|c|c|c|}
\hline \multirow{3}{*}{$\begin{array}{r}\mathrm{V}_{2} \mathrm{O}_{5}-\mathrm{MoO}_{3} \\
\quad(1 \mathrm{~mol} \%)\end{array}$} & 121 & 76 & 14.5 & 13.1 \\
\hline & " & 152 & 15.7 & 14.6 \\
\hline & " & 304 & 16.0 & 15.9 \\
\hline \multirow{3}{*}{$\begin{array}{c}\mathrm{V}_{2} \mathrm{O}_{5}-\alpha-\mathrm{Al}_{2} \mathrm{O}_{3} \\
(1 \mathrm{~mol} \%)\end{array}$} & 121 & 76 & 12.1 & 10.0 \\
\hline & $" 1$ & 152 & 12.6 & 12.5 \\
\hline & " & 304 & 13.7 & 14.5 \\
\hline
\end{tabular}
た結果は表 6 に示したが，これらは $\log V_{O} \sim 1 / T$ の作図から求 めた $E_{\mathrm{A}}$ に近い值を示している。

表 $6 \mathrm{~V}_{2} \mathrm{O}_{5}-\mathrm{MoO}_{3}(1 \mathrm{~mol} \%), \mathrm{V}_{2} \mathrm{O}_{5}-\alpha-\mathrm{Al}_{2} \mathrm{O}_{3}(1 \mathrm{~mol} \%)$ 触媒による一酸化炭素酸化の見汃けの活性化熱 $E_{\mathrm{A}}$

触 媒 $\quad \begin{gathered}P_{\mathrm{O}_{2}} \\ (\mathrm{mmHg})\end{gathered} \underset{(\mathrm{mm} \mathrm{Hg})}{P_{\mathrm{Co}}} \underset{(\mathrm{kcal} / \mathrm{mol})}{E_{\mathrm{A} \text { obs }}} \underset{(\mathrm{kcal} / \mathrm{mol})}{E_{\mathrm{A}} \text { cals }}$

以上の取り扱いで明らかなように酸化モリブデン( V )， $\alpha$-酸化 アルミニウムを添加した触媒では表面反応の活性化熱 $E か ゙$ 酸化バ ナジウム (V)単独の場合の值に比較してそれぞれ $6.0 \mathrm{kcal} / \mathrm{mol}$, $2.3 \mathrm{kcal} / \mathrm{mol}$ 減少していることがわかる。したがって酸化バナ ジウムに対する少量の酸化モリブデン（VI)， $\alpha$-酸化アルミニウム の作用についてはつぎのように考えることができる。すなわち酸 化モリブデン（VI）の添加は酸素，一酸化炭素の吸着熱が酸化バ ナジウム（V）単独に対するものよりやや小さい方向に作用して いることから $\theta_{\mathrm{O}}, \theta_{\mathrm{CO}}$ の減少をきたすが，表面反応の過程の活 性化熱のかなりの低下がそれを十分におぎなって助触媒として有 効に働いているわけである。一方 $\alpha$-酸化アルミニウムの添加で は一酸化炭素, 酸素の吸着熱が增すことにより $\theta 0, \theta_{\mathrm{Co}}$ の増加 をきたし，また表面反応の過程の少量の活性化熱の低下と相まっ て助触媒作用を営えでいるとみることができよう。

(1955 年 4 月, 日本化学会第 8 年会； 1956 年 4 月，触媒化学討 論会講演）

\title{
酸素，一酸化炭素，崖酸ガ八吸着にともなう酸化バナジゥム $(\mathbf{V})$ の電気伝導度の変化
}

(昭和 35 年 2 月 20 日受理)

多羅間公雄十・寺西士一郎十・服部研太郎十・安井炤夫胡

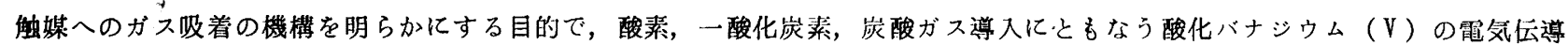
度の変化を追跡した。酸素導入にともなって酸化バナジウム $(\mathrm{V})$ の伝導度 $(\sigma)$ は減少し,その娍少速度は酸素吸祝初期に打いては, $-\mathrm{d} \sigma / \mathrm{d} t=k\left(\sigma-\sigma_{e}\right)$ の関係式で表わされ，また $k$ と酸素圧力 $p$ との間には Langmuir 型の関係が存在するととが見いだされ た。一酸化炭素の導入にともなっては伝導度は增加し，またての変化が非可逆的であるとと，打よび吸着初期の伝導度の増加は， $\mathrm{d} \sigma / \mathrm{d} t=k\left(\sigma_{e}-\sigma\right)$ で表わされることが見いだされた。炭酸ガス尊入にともなっては伝導度は娍少し，またての変化はきわめて小 さく，てれは吸着量のきわめて少ないためであるてとか，吸着实験からも雄かめられた。また炭酸ガス導入にともなら伝導度の变 化の方向は振動容量法による表面電位の測定絬果とも定性的に一致した。 


\section{1 緒論}

金属酸化物触媒の作用を物性論的な立場から㭘討しょうとする 試みが種々なされているが，これらの中で触媒の電気伝導度，ガ ス吸着にともなう伝導度の変化の測定を行なうことにより触媒活 性の本質, 反応機棈の究明に役立てようとする努力がなされてい ๖1)。

酸化バナジウム（V）についてのこの方面の研究としては，そ の電父伝導度を測定した報交 ${ }^{22}$ (6) は二，三みられるが，触媒活性 との関連性を明らかにする目的で行なわれたるのはない。

われわれは酸化バナジウム（V）触媒についてその物理的，化 学的諸性質と迻媒作用の関連性についてくわしく検討する目的で 一連の研究》を行なっており，前報8)では酸化バナジウム (V)

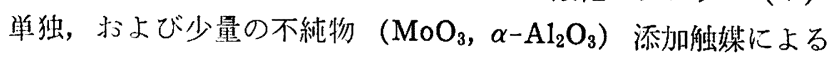
一酸化炭素酸化幾满について速度諭的に研究した結果を報告した が，本報では酸化バナジウム（V）単独触媒による酸素，一酸化 炭素, 炭酸ガスのガス導入にともなう酸化バナジウム $(V)$ の電 気伝導度の変化を追跡することにより, 触媒の表面状態, ガス吸 着機構について娭討を加えた。

\section{2 試料および実験法}

实験に伐用した酸化バナジウム（V) 試料は精製したバナジン 酸アンモニウムを， $450^{\circ} \mathrm{C} て ゙ 3$ 㭙間加熱分解してつくったもの でその表面積は $2.57 \mathrm{~m}^{2} / \mathrm{g}$ であった（炭酸ガスを用いて $-78^{\circ} \mathrm{C}$ で BET 法に上り測定)。

粉体の雪気伝䕗度の測定には Griffith ら9)が用いたものと類 似の装置によった。両白金電極 $\left(2.5 \mathrm{~cm}^{2}\right)$ 間に酸化バナジウム

（V） $1 \mathrm{~g}$ を捚入し，一定荷重 $(50 \mathrm{~g})$ の鉦を加光，ブリッジを 組むことにより伝導度の測定を行なった。粉体試料はいったん $550^{\circ} \mathrm{C}$ で 2 時間空気中で加熱することにより再現性のある安定 な抵抗測定試料となった。

酸素, 一酸化炭素, 炭酸ガスなどのガス吸着にともなう伝導度 の変化の測定には，容器を $1 \times 10^{-3} \mathrm{mmHg}$ に引き，これに一定 玨力のガスを導入し，封間的に抵抗値の変化を直流ブリッジで測 定した。このときガス吸着にともなう圧力変化はきわめて小さ く,このためとくに圧力変化の測定は行なわなかった。

酸素，一酸化炭素，炭酸ガスはそれぞれ常法により精製したも のを用いた。

\section{3 実験結果および考察}

\section{1 酸化バナジゥム（V) の電気伝導度}

酸化バナジウム $(\mathrm{V})$ の空気中ならびに真空中 $\left(1 \times 10^{-3} \mathrm{mmHg}\right)$ に打ける伝導度と温度の関係は図 1 に示した。測定値はいずれも 高温側より温度を下げた場合，すなわち，泠却曲線に刘応するる

1) た上えば T. J. Gray, P. W. Darby, J. Phys. Chem. 60, 201 (1956).

2) J. Boros, Z. Phys.126, 721 (1949),

3) B. M. Hokhbery, M. S. Somminski, Chem. Abst. 32, 1644(1938).

4) 河口, 日化 75, 94, 835 (1954).

5) 河口, 流酸 7, 403 (1954)

6) H. Clark, D. J. Berets, Advances in Catalysis 9, 204 (1957).

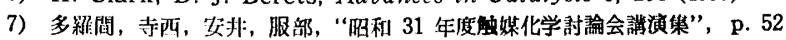
(1956)；多羅間，寺西，穻井，工化 60，1222 (1957).

8) 多罝間, 寺唒, 安井, 日化 81, 1034(1960).

9) R. H. Griffith, P. R. Chapman, J. D. F. Marsh, Proc. Roy. Soc. A224, 412 (1954).

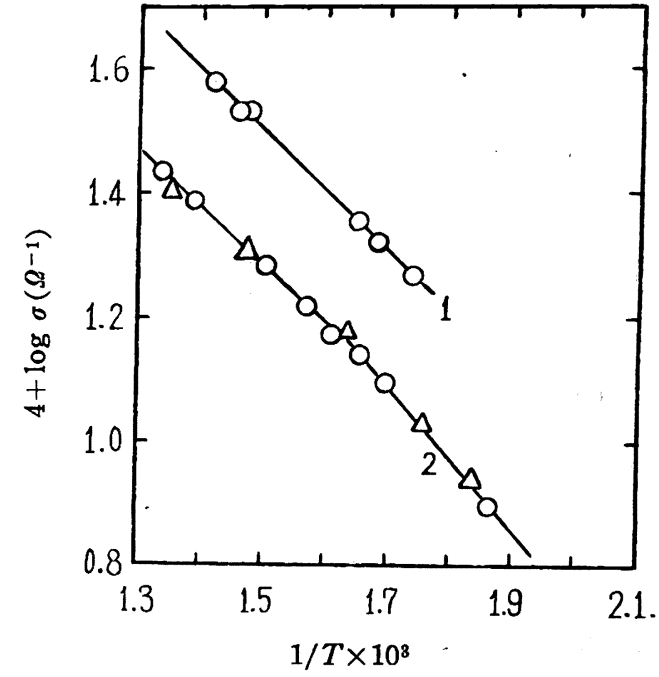

1: in Vaccum $\left(1 \times 10^{-8} \mathrm{mmHg}\right), 2$ : in air

図 $1 \mathrm{~V}_{2} \mathrm{O}_{5}$ の電気伝導度 $\log \sigma \sim 1 / T$ の plot

のであり，この方法による粉体の抵抗值はその再現性が良好であ った。

伝導度 $\sigma$ と温度との関係は,

$$
\begin{aligned}
& \sigma=\sigma_{0} \mathrm{e}^{-E_{\sigma} / R T} \\
& \sigma_{0}: \text { 定数 }
\end{aligned}
$$

で与えられる。空気中における測定結果では $\log \sigma \sim 1 / T$ の関俰 は二つの直線部分からなっている。また高温域の伝導の活性化熱 は低温域のそれの約 $1 / 2$ に等しい。多数の凍結した伝導中心をむ つ半尊体では上記の現象に類似の挙動を示すことが Nijboer ${ }^{10)}$ の理諭から予想されるが，われわれの用いた試料は高温処理のた めこのような状態にあると考えられる。低温域。高温域における 伝導の活性化熱, 臨界温度 $T_{\mathrm{e}}$ は表 1 に示した。

$\begin{array}{cccc}\text { 表 } 1 & \text { 酸化バナジゥム }(\mathrm{V}) \text { の電気层導度の活性化熟 } E_{\text {。 }} \\ \text { 武料 } & \text { 高温域 }\left(>350^{\circ} \mathrm{C}\right) & \text { 低温域 }\left(<350^{\circ} \mathrm{C}\right) & T_{\mathrm{c}}\left({ }^{\circ} \mathrm{C}\right) \\ \mathrm{V}_{2} \mathrm{O}_{5} & 0.090 \mathrm{eV} & 0.175 \mathrm{eV} & 350\end{array}$

真空中 $\left(1 \times 10^{-8} \mathrm{mmHg}\right)$ における伝導度は図 1 から明らかな ように，酸素圧力の滅少にともなって伝導度は增加し， $n$ 型半導 体の特徵を示している。この場合の伝導の活性化熱は空気中のそ れとほぼ同一で，むたこの低温域の $E_{\sigma}$.は単結晶を用いて測定さ れた Boros $^{2}$ の值 $0.2 \mathrm{eV}$ と大体一致している。

\section{2 酸素吸着にともなう伝等度の变化}

一定圧力の酸素を導入したときの伝導度の変化は図 2,3 K一 部示した。酸素導入にともなって酸化バナジウム（V）の伝導度 は減少するが，これは酸素が電子受容体となっていることを示す ものである。またこのときの伝導度の変化の過程は可逆的で, 実 験終了後真空に排気することによりるとの伝導度の值にもどっ た。四 2 にも示したように比較的低温度 $\left(384^{\circ} \mathrm{C}\right)$ においては抵 抗変化 $\Delta R$ と時間との関係は，吸着初期における比較的急激な変 化の部分, つづいて直線的に変化する部分, お上び抵抗值の変化 の少ない準平衝状態に達した部分からなっている。温度が上㫒す るにしたがって上記の直線部分に相当する期間が短かくなる傾向 を示した。吸着初期の部分はいずれの温度でも，

$$
-\frac{\mathrm{d} \sigma}{\mathrm{d} t}=k\left(\sigma-\sigma_{e}\right)
$$

10) B. R. A. Nijboer, Proc. Phys. Soc. 51, 575 (1939). 


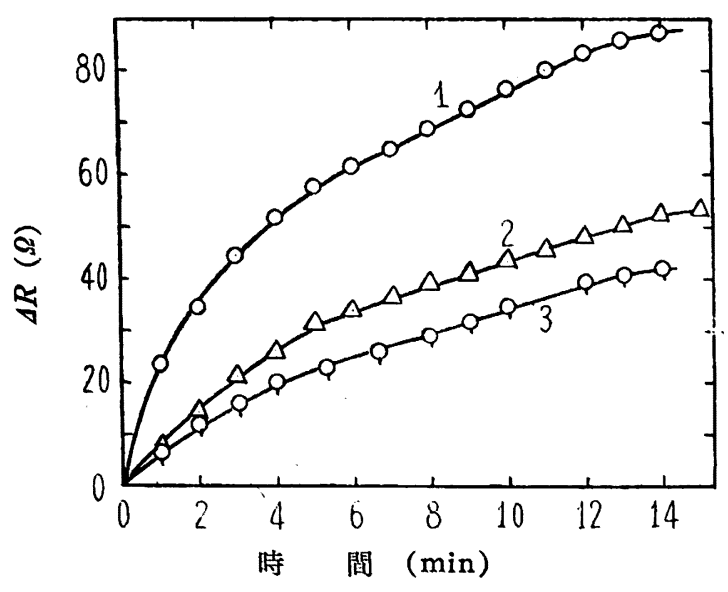

1: $27.4 \mathrm{mmHg}, 2: 13.0 \mathrm{~mm} \mathrm{Hg}, 3: 6.6 \mathrm{mmHg}$

図 2 酸秦吸着にともなう $\mathrm{V}_{2} \mathrm{O}_{5}$ の抵抗変化 $\Delta R(\Omega)$ (温度 $384^{\circ} \mathrm{C}$ )

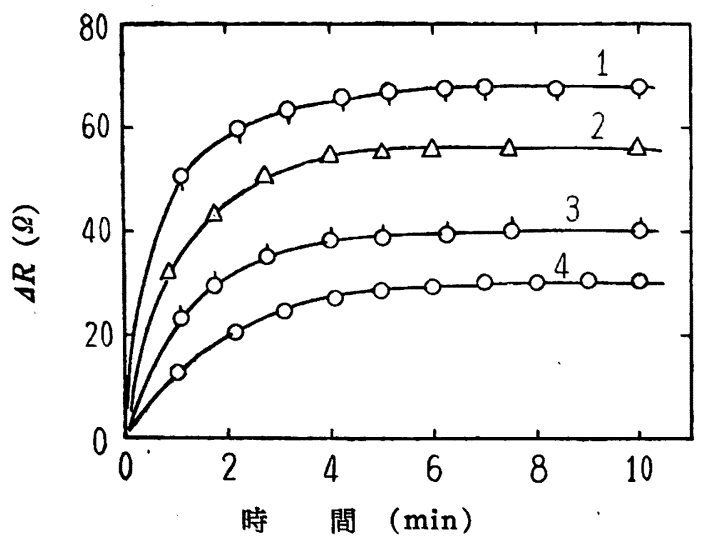

1: $19.3 \mathrm{mmHg}, \quad 2: 8.9 \mathrm{mmHg}$,

3: $4.0 \mathrm{mmHg}$, '4: $2.0 \mathrm{mmHg}$,

困 3 酸素吸着にともなう $\mathrm{V}_{2} \mathrm{O}_{3}$ の抵抗変化 $\Delta R(\Omega)$ (温度 $448^{\circ} \mathrm{C}$ )

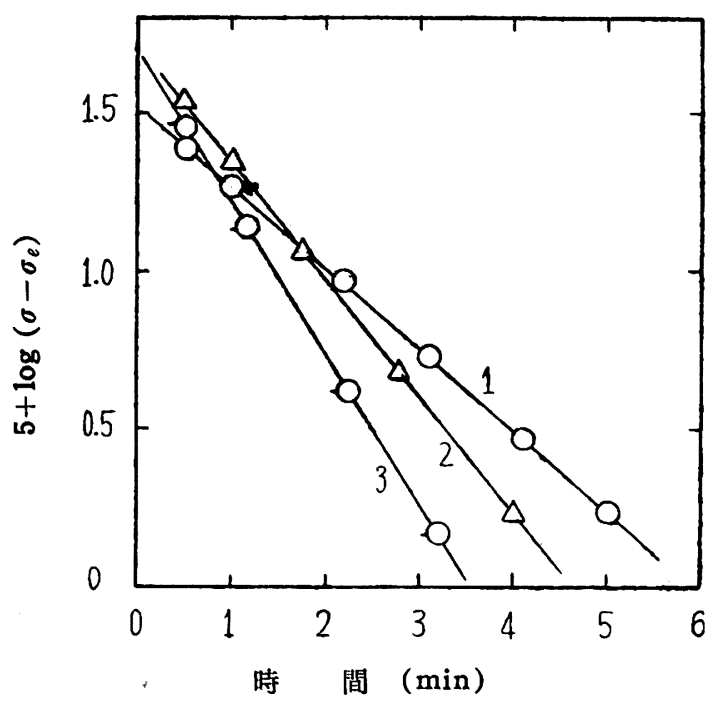

1: $2.0 \mathrm{mmHg}, 2: 8.9 \mathrm{mmHg}, 3: 19.3 \mathrm{mmHg}$

圀 4 酸素吸着にともなう $\mathrm{V}_{2} \mathrm{O}_{5}$ の伝導度の変化 $\left(\right.$ 温度 $\left.448^{\circ} \mathrm{C}\right) \log \left(\sigma \sim \sigma_{c}\right) \sim t$ の plot

$\ln \left(\sigma-\sigma_{e}\right)=\ln \left(\sigma_{0}-\sigma_{e}\right)-k t$

$\sigma_{e}$ ：準平衡時における伝導度

$\sigma_{0}: t=0$ における伝導度
なる閶係式を满足している。兴 4 は $\left(2^{\prime}\right)$ 式にしたがって $\ln \left(\sigma-\sigma_{c}\right)$ Ł $t$ この関係它示したものである。この直線の傾き から $k$ が求められる。

図 5 汇このようにして求められた $k$ の值と酸素生力との関係を 示したものである。 $k$ と $P_{\mathrm{O}_{2}}$ の間には Langmuir Isotherm に 類似した関係, 玄なわ方 $1 / k$ 己 $1 / P_{\mathrm{O}_{2}}$ この作図に直線関係の存在

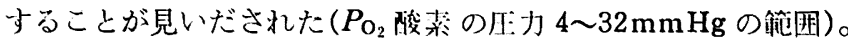

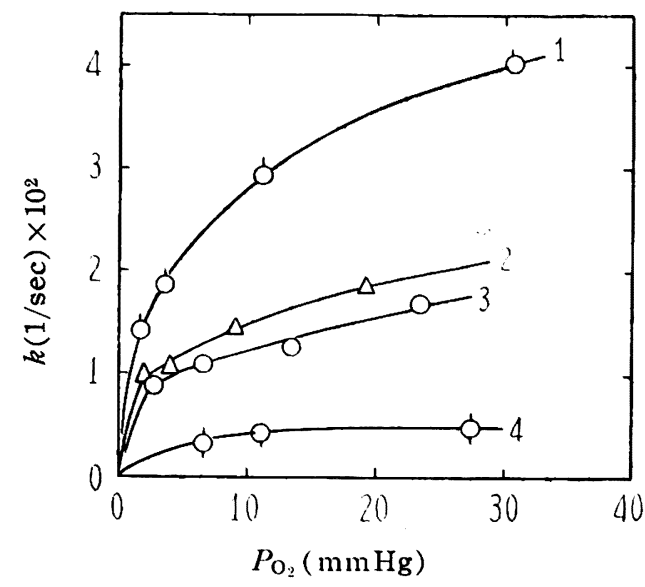

1: $418^{\circ} \mathrm{C}, 2: 448^{\circ} \mathrm{C}, 3: 452^{\circ} \mathrm{C}, 4: 384^{\circ} \mathrm{C}$

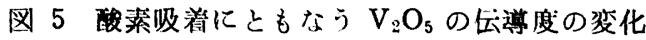
$k \sim P_{\mathrm{O}_{2}}$ の関係

\section{3 一酸化岸秦吸着にともなう伝荟度の变化}

一酸化炭素導入にともなう㐾導度の变化は目 6 に一部示した。 このとき一酸化炭素の忣着にともなって伝導度は增加するが，尖 験終了後装置を真圭に引いても伝導度は变わらず，もとの值にも どらない。与なわち一酸化炭素吸渞による伝導度の変化は非可逆 的である。このことは吸着した一酸化炭素が粉体表面で安定な化 学結合をつくっているか, 裴面酸集と反応して炭酸ガスこなり脱 離したためと考えられる。

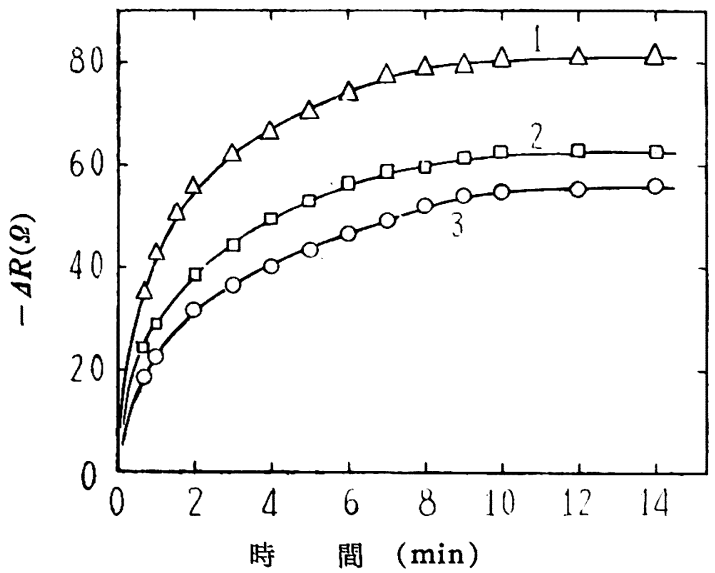

1: $19.0 \mathrm{~mm} \mathrm{Hg}, 2: 9.0 \mathrm{~mm} \mathrm{Hg}, 3: 4.3 \mathrm{~mm} \mathrm{Hg}$ 図 6 一酸化炭絮投着に上もなう $\mathrm{V}_{2} \mathrm{O}_{5}$ の伝学度 の変化 (温废 $442^{\circ} \mathrm{C}$ )

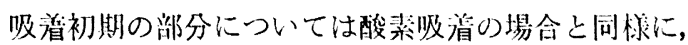

$$
\frac{\mathrm{d} \sigma}{\mathrm{d} t}=k\left(\sigma_{\mathrm{r}}-\sigma\right)
$$

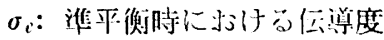

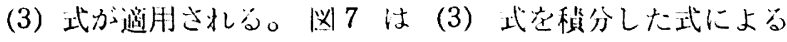




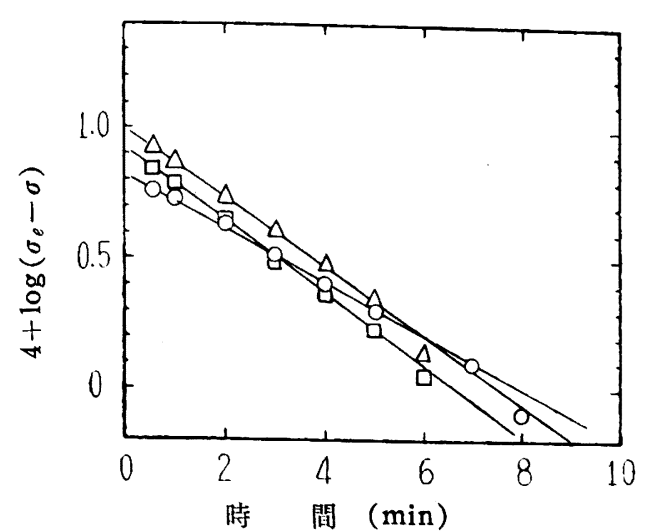

$\bigcirc: 4.3 \mathrm{mmHg}, \square: 9.0 \mathrm{mmHg}, \triangle: 19.0 \mathrm{mmHg}$

网 7 一酸化炭素吸着にともなう $\mathrm{V}_{2} \mathrm{O}_{5}$ の伝導度の变化 (混度 $442^{\circ} \mathrm{C}$ ) $\log \left(\sigma_{e}-\sigma\right) \sim t$ の plot

$\log \left(\sigma_{e}-\sigma\right)$ と $t$ との関係を示したものである。この直線の傾き から $k$ が算出されるが, 各温度において $k$ と $P_{\text {Co }}$ との関係を示 したのが図 8 である。同図から明らかなように $k$ の温度による变 化はわずかであり，また $P_{\text {co }}$ との関係も測定圧力範囲ではほぼ 一走であるが，P Po の小い部分では $k$ は漸次低下与る傾向があ 万 $\left(442^{\circ} \mathrm{C}\right)$ 。

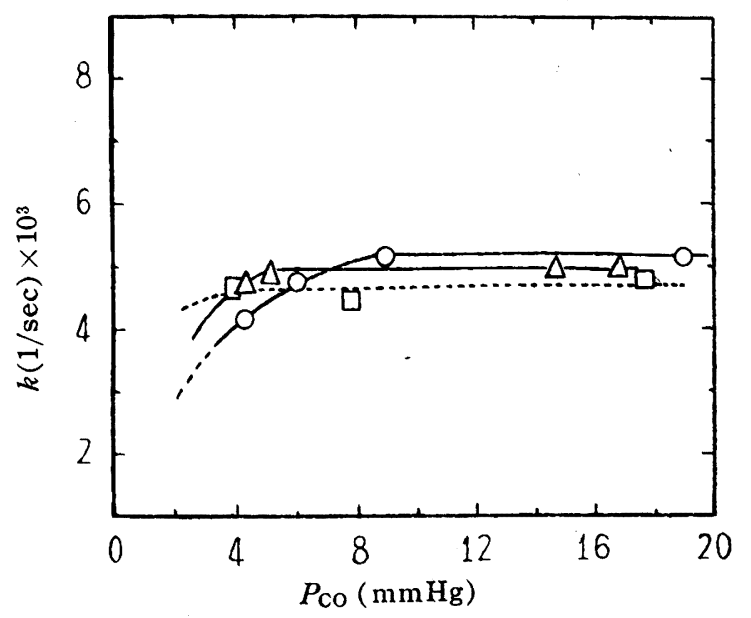

O: $442^{\circ} \mathrm{C}, \triangle: 426^{\circ} \mathrm{C}, \square: 380^{\circ} \mathrm{C}$

図 8 一酸化筷素财着にともなう $\mathrm{V}_{2} \mathrm{O}_{5}$ の伝導度の 変化 $k \sim P_{\text {co }}$ の関係

\section{4 炭酸ガ ス吸着にともなう伝㮍度の変化}

炭酸ガス導入にともなう伝導度の変化は表 2 に示した。

表 2 炭酸ガス吸着による抵抗值の変化

$\begin{array}{ccc}\text { 温度 }\left({ }^{\circ} \mathrm{C}\right) & P_{\mathrm{CO}_{2}}(\mathrm{mmHg}) & \Delta R(\Omega)\left(\Delta R=R_{f}-R_{i}{ }^{a}\right) \\ 456 & 23.9 & +2.5 \\ " & 22.2 & +2.2 \\ " & 16.5 & +0.7 \\ 396 & 36.5 & +1.7 \\ & 20.0 & +0.8\end{array}$

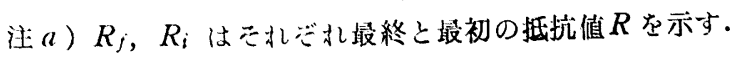

この場含伝詯度の変化はきわめて少ないが，炭酸ガス财着によ

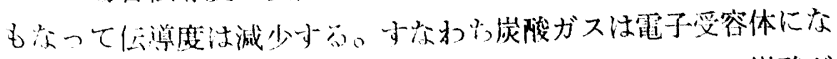

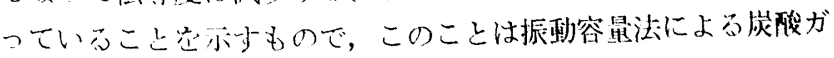

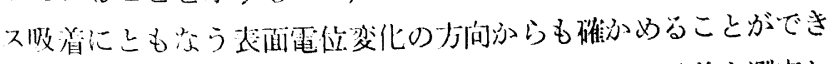
た。别に酸化バナジウム（V）に刘する炭酸ガスの忣着を測定し
たところ，伝導度の測定条件下の温度範囲では，炭酸ガスの吸着 はほとんど起らず，これは上記の伝導度に対する変化がきわめて 少ないことと定性的に一致している。

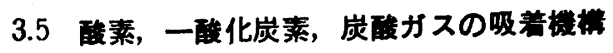

酸化バナジウム（V）に対する酸素の吸着は解䜅吸着であるこ とが前報8)の吸着実験から明らかにされたが，このことと上述の 酸素吸着にともない伝導度が減少与る模様から, 吸着の機構とし てつぎのようなむのが考えられる。

$$
\begin{aligned}
& \mathrm{O}_{2}+e \stackrel{K_{1}}{\rightleftarrows} \mathrm{O}_{2}^{-}(\mathrm{ad}) \\
& \mathrm{O}_{2}{ }^{-}(\mathrm{ad})+e-\mathrm{A} \rightarrow 2 \mathrm{O}^{-}
\end{aligned}
$$

まず (4) 式のように酸素分子が表面に物理吸着に近い形で吸着す ろが, この過程はきわめて早く平衡状態になる。ついで $\mathbf{O}_{2}{ }^{-}(\mathrm{ad})$ は解離して O-イオンとなる。この财着分子の解耀が律速段階と ナると, 酸素吸着による伝導度の変化は,

$$
\frac{\mathrm{d} \sigma}{\mathrm{d} t}=k^{\prime}\left[\mathrm{O}_{2}^{-}(\mathrm{ad})\right]\left[\sigma_{\rho}-\sigma\right]
$$

（6）式で表わされる。

$$
\begin{aligned}
& {\left[\mathrm{O}_{2}{ }^{-}(\mathrm{ad})\right]=\frac{S K_{1} P_{\mathrm{O}_{2}}}{1+K_{1} \cdot P_{\mathrm{O}_{2}}}} \\
& K_{1} \text { : 平尖定数 } \\
& S: \text { 有効吸着表面積 (最大吸着可能量) }
\end{aligned}
$$

(7) 式の関係を（6）式に代入して，

$$
\left.\begin{array}{rl}
\frac{\mathrm{d} \sigma}{\mathrm{d} t} & =k\left(\sigma_{e}-\sigma\right) \\
k & =\frac{k^{\prime} K_{1} \cdot P_{\mathrm{O}_{2}} S}{1+K_{1} \cdot P_{\mathrm{O}_{2}}}
\end{array}\right\}
$$

(8) 式が得られ, これから $\log \left(\sigma-\sigma_{\theta}\right) \sim t$ の直線関係および $k$ と $P_{\mathrm{O}_{2}}$ との間に Langmuir 型の関係があるという実験結果を説 明することができる。

一酸化炭素吸着では吸着により伝導度は増加し，またこの過程 が非可逆的であることから考えて吸着一酸化炭素は一部炭酸ガス として脱膗するが，一部は表面で安定な $\mathrm{CO}^{2}{ }^{2-}$ ，をつくるとも考 えられる11。ところで一酸化炭素吸着の機構として，

$$
\begin{aligned}
\mathrm{O}^{2-}(\mathrm{L})+\mathrm{CO} \rightleftarrows & \mathrm{CO}-\mathrm{O}^{2-}(\mathrm{L}) \\
& (\mathrm{Co}(\mathrm{ad})) \\
\mathrm{CO}-\mathrm{O}^{2-}(\mathrm{L})-\mathrm{A} \rightarrow & \mathrm{CO}_{2} \uparrow+\left[\mathrm{O}_{\mathrm{v}}^{2+}\right]^{\Theta}+e
\end{aligned}
$$
または,

$$
\mathrm{O}:-(\mathrm{L})+\mathrm{CO}-\mathrm{O}^{2-}(\mathrm{L})-\mathrm{A} \rightarrow \mathrm{CO}_{3}{ }^{2-}+\left[\mathrm{O}_{\mathrm{v}}{ }^{2+}\right] \Theta+B
$$

$\mathrm{O}^{2-}(\mathrm{L})$ : 表面の格子点 $\mathrm{O}^{2-}$ イオン

$\left[\mathrm{O}_{\mathrm{v}}{ }^{2+}\right]$ ：酸素原子の抜けた anion vacancy

苍考え（10）式が律速段階と与れば吸着による伝導度の変化は，

$$
\frac{\mathrm{d} \sigma}{\mathrm{d} t}=k^{\prime}[\mathrm{CO}(\mathrm{ad})]\left[\sigma_{e}-\sigma\right]
$$

となり酸素吸寿の場合と同橡に吸着による伝導度の变化を説明す えことができる。

炭陖ガスについては收着により伝導度がわずかに減少すること から酸秦の場合上同じく単に電子受容体として働いているのであ 少。

本研究の䟧用の一部は文部省科学研究助成金によった。 （1955 位：4月，日本化学会第 8 年会諈演）

11) W. E. Garner, T. J. Gray, F. S. Stone, Discuss. Faraday Soc. B. $246(1950)$. 
VII. Structural Viscosity and Spinnability. Part. 3 (pp. 1020 1025)

The spinnability and structural viscosity of acetyl cellulose $(15,20,21,24,25 \%)$-acetone-water mixtures are investigated. The conclusion is the same as the previous one $(\mathrm{VI}), i . e$, the spinnability of the solutions $(20,21,24,25 \%)$ depends mainly on the viscoelastic relaxation phenomena. But the spinnability of $15 \%$ solution is in the mediate region between the viscous flow and the relaxation phenomena, because the relaxation time of $15 \%$ solution is smaller $\left(10^{-2} \sim 10^{-3} \mathrm{sec}\right.$.) than the others $\left(10^{-1} \sim 10^{-2}\right.$ sec. $)$. The results obtained in VI and VII show that the elementary process of spinning in the authors' experiment has the characteristic period of order of $10^{-2}$ sec., though it is much smaller than the actual interval of spinning (spinning length/spinning velocity 1 sec.).

Faculty of Science, Niigata University; Niigata-shi, Niigata, Japan

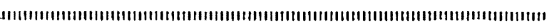

Nippon Kagaku Zasshi, 81, 1025 1028 (1960)

NMR Study on the Solvent Effect of the Fatty AcidAromatic Compound System

by Hiroshi SHIMIZU

The dilution shifts of the proton magnetic resonance of the fatty acid-benzene and fatty acid-pyridine systems were measured. The fatty acids used in this experiment were acetic acid, dichloroacetic acid, propionic acid, $n$-butyric acid, iso-butyric acid, and iso-valeric acid. From the results of the experiment, it was found that; (1) a sort of bond was formed between the $\pi$ electron in the benzene ring and the methyl hydrogen of the fatty acid, (2) the strength of this bond seemed to depend on the chemical activity of the methyl hydrogen, (3) in the system of a basic solvent such as pyridine, the active methyl hydrogen was considered to behave as a weak acid, (4) $\pi \cdots \mathrm{H}-\mathrm{O}$ type bond was found to be formed between the carboxylic hydrogen and the $\pi$ electron system, (5) benzene was found to behave as a polar solvent for the fatty acid, (6) the fatty acids except dichloroacetic acid depolymerized stepwise as polymer $\rightarrow$ dimer $\rightarrow$ monomer when diluted by benzene, however, dichloroacetic acid depolymerized monomer in one step, and (7) the signals of $\beta, \gamma$-hydrogens of the pyridine molecule showed the lower field shifts of the magnitude of $0.6 \sim 0.85$ p. p. m., whereas those of $\alpha$-hydrogen did not show such a large shift. This phenomenon can be attributed to the change of the electronic distribution in the pyridine molecule due to the formation of the $y \mathrm{~N} \cdots \mathrm{H}-\mathrm{O}$ bond.

Faculty of Pharmaceutical Sciences, University of Tokyo; Bunkyo-ku, Tokyo, Japan

Nippon Kagaku Zasshi, 81, 1028 1034 (1960)

Characteristic Frequencies in the Infrared Spectra of Orthoaliphatic Acid Esters

by Kenkichi NUKADA

Infrared spectra of compounds having $\mathrm{C}(\mathrm{OR})_{3}$ skeleton (trimethyl orthoformate, trimethyl orthoacetate, trimethyl ortho- $n$-valerate, triethyl orthoformate, tri- $n$-butyl orthoformate and triethyl orthopropionate) were obtained in $\mathrm{LiF}$ and $\mathrm{NaCl}$ prism regions. From the comparison of these spectra with each others, vibrational modes of functional groups were assigned as follows in liquid state: $2996 \pm 3 \mathrm{~cm} .^{-1}\left(\mathrm{CH}_{3} \mathrm{O}, \mathrm{CH}_{3}\right.$ asym. stretch. $), 2979 \pm 2$ cm. ${ }^{-1}\left(\mathrm{C}_{2} \mathrm{H}_{5} \mathrm{O}, \mathrm{CH}_{3}\right.$ asym. stretch. $), 2960 \mathrm{~cm} .^{-1}\left(\mathrm{CH}_{3}\left(\mathrm{CH}_{2}\right)_{n}\right.$ $\mathrm{C}-\mathrm{O}, n=2,3, \mathrm{CH}_{3}$ asym. stretch. $), 2943 \pm 5 \mathrm{~cm} .^{-1}\left(\mathrm{CH}_{3} \mathrm{O}\right)$, $2933 \pm 1 \mathrm{~cm}^{-1}\left(\mathrm{C}-\mathrm{O}-\mathrm{CH}_{2}, \mathrm{CH}_{2}\right.$ asym. stretch.), $2881 \pm 8 \mathrm{~cm} .^{-1}$ $\left(\mathrm{C}_{2} \mathrm{H}_{5} \mathrm{O}\right.$ and $\mathrm{CH}_{3}\left(\mathrm{CH}_{2}\right)_{n} \mathrm{C}-\mathrm{O}, n=1,2,3, \mathrm{CH}_{3}$ sym. stretch. $)$, $2838 \pm 1 \mathrm{~cm}^{-1}\left(\mathrm{CH}_{3} \mathrm{O}\right), 1455 \pm 22 \mathrm{~cm} .^{-1}\left(\mathrm{CH}_{3}\right.$ asym. deform.), $1369 \pm 16 \mathrm{~cm} .^{-1}\left(\mathrm{CH}_{3}\right.$ sym. deform. $\mathrm{CH}_{2}$ scissoring and wag., and $\mathrm{CH}$ deform. $), 1342 \sim 1258 \mathrm{~cm} .^{-1}\left(\mathrm{CH}_{2}\right.$ wag. and twist.), $1230 \pm 9, \quad 1170 \sim 1100$ and $1070 \sim 1035 \mathrm{~cm} .^{-1}\left(-\mathrm{C}\left(\mathrm{OCH}_{3}\right)_{3}\right.$ skeletal), $1100 \sim 1010 \mathrm{~cm}^{-1}\left(\mathrm{HC}\left(\mathrm{OCH}_{2}\right)_{3}\right.$ skeletal $), 1050$ and $1010 \sim 980 \mathrm{~cm} .^{-1}\left(-\mathrm{CH}_{2} \mathrm{C}\left(\mathrm{OCH}_{2}\right)_{3}\right.$ skeletal $), 903 \pm 23 \mathrm{~cm} .^{-1}$ $\left(\mathrm{CH}_{3} \mathrm{O}, \mathrm{CH}_{3}\right.$ rocking) and below $890 \mathrm{~cm} .^{-1}\left(\mathrm{CH}_{2}\right.$ rocking). This assignment is consistent with that of formals and acetals discussed in the preceding paper.

The Government Chemical Industrial Research Institute of Tokyo; Shibuya-ku, Tokyo, Japan

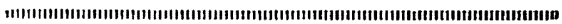

Nippon Kagaku Zasshi, 81, 1034 1038 (1960)

Oxidation Mechanism of Carbon Monoxide on $\mathrm{V}_{2} \mathrm{O}_{5}$ Catalysts

by Kimio TARAMA, Shiichiro TERANISHI and Teruo YASUI

A kinetic investigation was conducted on the $\mathrm{V}_{2} \mathrm{O}_{5}$ catalysed oxidation of carbon monoxide and on the promotor action of $\mathrm{MoO}_{3}$ and $\alpha-\mathrm{Al}_{2} \mathrm{O}_{3}$ on the catalyst. The adsorption isotherms of oxygen on the catalyst satisfied the Langmuir's equation of dissociative adsorption, and values of $20.3,15.3$ and $22.7 \mathrm{kcal} . / \mathrm{mol}$. were obtained for the heat of adsorption for oxygen on $\mathrm{V}_{2} \mathrm{O}_{5}$, $\mathrm{V}_{2} \mathrm{O}_{5}-\mathrm{MoO}_{3} \quad(1 \mathrm{~mol} \%)$, and $\mathrm{V}_{2} \mathrm{O}_{5}-\alpha-\mathrm{Al}_{2} \mathrm{O}_{3}$ ( $\left.1 \mathrm{~mol} . \%\right)$ respectively. The rate-determining step in the oxidation was found to be the surface reaction between the adsorbed carbon monoxide and the adsorbed oxygen. Values of $28.4,22.4$ and $26.1 \mathrm{kcal} / \mathrm{mol}$. were obtained for the activation energy of this process on $\mathrm{V}_{2} \mathrm{O}_{5}, \mathrm{~V}_{2} \mathrm{O}_{5}$ $\mathrm{MoO}_{3}$ and $\mathrm{V}_{2} \mathrm{O}_{5}-\alpha-\mathrm{Al}_{2} \mathrm{O}_{3}$ respectively. The results, being kinetically analyzed, showed that the promotor action of $\mathrm{MoO}_{3}$ on $\mathrm{V}_{2} \mathrm{O}_{5}$ consisted in the decrease in the activation energy of surface reaction, and that addition of $\alpha$ $\mathrm{Al}_{2} \mathrm{O}_{3}$ on $\mathrm{V}_{2} \mathrm{O}_{5}$ increased $\theta_{\mathrm{CO}}, \theta_{\mathrm{O}}\left(\theta_{\mathrm{CO}}, \theta_{\mathrm{O}}\right.$ are defined as fraction of surface covered by adsorbed carbon monoxide and oxygen respectively) and made the activation energy of the surface reaction slightly lower.

Department of Fuel Chemistry, Faculty of Engineering, Kyoto University; Sakyo-ku, Kyoto, Japan

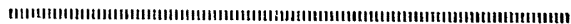

Nippon Kagaku Zasshi, 81, 1038〜1041 (1960)

Changes of Electric Conductivity of $\mathrm{V}_{2} \mathrm{O}_{5}$ Accompanied with Adsorption of Oxygen, Carbon Monoxide and Carbon Dioxide

by Kimio TARAMA, Shiichiro TERANISHI, Kentaro HATTORI and Teruo YASUI

The changes of electric conductivity of $\mathrm{V}_{2} \mathrm{O}_{5}$ accompanied with the adsorption of oxygen, carbon monoxide and carbon dioxide were measured to elucidate the adsorption processes of these gases. The conductivity of $\mathrm{V}_{2} \mathrm{O}_{5}$ decreased as the adsorption of oxygen proceeded, and it was found that the rate of this initial process satisfied the equation $-\mathrm{d} \sigma / \mathrm{d} t=\left(k \sigma-\sigma_{\mathrm{e}}\right)$ and that the linear relation existed between $1 / k$ and $1 / p$ ( $p$; oxygen pressure). On the other hand, the conductivity increased 
for the adsorption of carbon monoxide. The experimental results showed that this adsorption belonged to an irreversible process and that the rate to this initial process satisfied the equatio $\frac{\mathrm{d} \sigma}{\mathrm{d} t}=k\left(\sigma_{\mathrm{e}}-\sigma\right)$. The conductivity of $\mathrm{V}_{2} \mathrm{O}_{2}$ decreased as the adsorption of carbon dioxide proceeded. In this case only a very little change was observed, and this is attributed to the small amount of carbon dioxide to be adsorbed. The surface potential of $\mathrm{V}_{2} \mathrm{O}_{5}$ was measured by the vibrating condenser method to follow the adsorption process of carbon dioxide. The change in the surface potential was found to be of the same sign as that in the conductivity.

Department of Fuel Chemistry, Faculty of Engineering, Kyoto University; Sakyo-ku, Kyoto, Japan

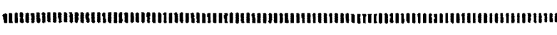

Nippon Kagaku Zasshi, 81, 1042 1047 (1960)

Infrared Spectra of tert-Butanol and its Deuterium Substituted Derivatives

by Chizuko TANAKA

The infrared spectra of tert-butanol $\left(\mathrm{CH}_{3}\right)_{3} \mathrm{COH}$ and its deuterium substituted derivatives $\left(\mathrm{CH}_{3}\right)_{3} \mathrm{COD},\left(\mathrm{CD}_{3}\right)_{3}$ $\mathrm{COH},\left(\mathrm{CD}_{3}\right)_{3} \mathrm{COD}$ have been observed in the liquid and gaseous states, and the Raman spectra of $\left(\mathrm{CH}_{3}\right)_{3} \mathrm{COH}$ and $\left(\mathrm{CD}_{3}\right)_{3} \mathrm{COH}$ have been observed in the liquid state. From these data, an assignment of the observed bands has been made to the normal modes of tert-butanol, and the result is in good agreement with the requirements of the product rule. On the deuteration of a hydroxyl group of tert-butanol, bands at 1330 and $1140 \mathrm{~cm} .^{-1}$ of gaseous $\left(\mathrm{CH}_{3}\right)_{3} \mathrm{COH}$ disappear and new bands appear at 1250 and $876 \mathrm{~cm}^{-1}$. Similar changes in the spectrum are observed on the deuteration of $\left(\mathrm{CD}_{3}\right)_{3} \mathrm{COH}$. The bands at 876 and $1250 \mathrm{~cm} \cdot{ }^{-1}$ of gaseous $\left(\mathrm{CH}_{3}\right)_{3} \mathrm{COD}$ have been assigned respectively to the in-plane $\delta(O D)$ vibration and to one of the skeletal stretching vibrations. It has been concluded that the in-plane $\delta(\mathrm{OH})$ mode of tertbutanol $\left(\mathrm{CH}_{3}\right)_{3} \mathrm{COH}$ is coupled with one of the $\nu$ (skeletal) modes, giving rise to the two mixed vibrations with the frequencies 1330 and $1140 \mathrm{~cm} .^{-1}$

Department of Chemistry, Faculty of Science, University of Tokyo; Bunkyo-ku, Tokyo, Japan

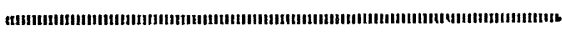

Nippon Kagaku Znsshi, 81, 1047 1049 (1960)

Difference between Anionic and Cationic Surfactants in Electroconductivity Behavior

\section{by Tamotsu KONDO and Kenjiro MEGURO}

A series of anionic surfactants with various gegenions arranged in the magnitude of their electroconductivity remains unchanged, while the series for cationic surfactants changes to reversed one, when the measurements were done above and below their C. M. C. These facts were explained taking account of the mobility and the amount of fixed gegenions on the micelle surface. The estimation on the amount of fixed gegenions was done with the consideration on two kinds of interaction; one is between micelle ions and dipoles which are induced in gegenions by the micelle ions and the other is the coulombic interaction between micelle ions and gegenions. It was found that the interaction between micelle ions and dipoles can not be neglected in the case of cationic surfactants because of large polarizability of gegen anions and that the amount of flxed gegenions increases as the ion-dipole interaction becomes stronger. It was concluded, therefore, that the electroconductivity of anionic surfactants with the same surface active ion is mainly determined by the mobility of gegenions, while that of cationic surfactants is determined by the amount of gegenions which is free from the micelle.

Nezu Chemical Laboratory, Musashi University; Nerima-ku, Tokyo, Japan

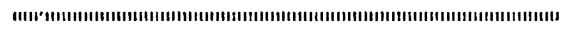

\section{Inorganic Chemistry and Geochemistry}

Nippon Kagaku Zasshi, 81, 1049 1055 (1960)

Chemical Studies on Minerals Containing Rarer Elements from the Far East Districts. XLVIII LI.

by Teikichi KAWAI

XLVIII. A Mineral of the Ishikawaite Category, Belonging to the Samarskite Series, from Iriyama, Ishikawa-machi, Fukushima Prefecture (pp. 1049 1051)

On minerals containing rarer elments, differences in their occurrence and localities at which they are found make a considerable difference in their composition, especially in the amount of rarer elements contained, even though these minerals may belong to the same category and bear the same mineralogical name. Thus if a mineral of the same category is found in a different locality, it is necessary, and at the same time geochemically interesting, to make chemical and mineralogical determination of its composition and nature. On the subject mineral were carried out chemical and spectrochemical analyses together with mineralogical determinations such as specific gravity, radioactivity, $\mathrm{X}$-ray diffraction, etc.

The results of the chemical analyses are as follows: $\mathrm{MgO} 0.70 \%, \mathrm{CaO} 0.00 \%, \mathrm{MnO} 1.10 \%, \mathrm{FeO} 12.17 \%, \Sigma \mathrm{Y}_{2} \mathrm{O}_{3}$ $7.21 \%, \mathrm{CeO}_{2} 0.00 \%, \mathrm{ThO}_{2} 0.00 \%, \mathrm{TiO}_{2} 0.68 \%, \mathrm{SnO}_{2}$ etc. $0.00 \%, \quad \mathrm{UO}_{2} 23.14 \%, \mathrm{UO}_{3} 5.15 \%$, (Nb, Ta) ${ }_{2} \mathrm{O}_{5} 49.35 \%$, $\mathrm{H}_{2} \mathrm{O} 1.11 \%$. According to X-ray diffraction patterns, this mineral appers to be samarskite but the chemial analyses show its composition to be slightly different. The ratio of urania to rare earths is higher in the ishikawaite than in the samarskite and this is one of the properties by which the two can be distinguished. As the ratio of uranium to rare earths is higher than that in the ishikawaite, the subject mineral can be considered to be the uranium rich member of the samarskite series.

XLIX. IImenorutile from Uzumine, Sukagawa-shi, Fnkushima Prefecture (p. 1052)

The results of the chemical analyses are as follows: $\mathrm{MgO} 2.43 \%, \mathrm{CaO} 1.52 \%, \mathrm{MnO} 15.96 \%, \mathrm{FeO} 19.12 \%, \mathrm{Al}_{2} \mathrm{O}_{3}$ $5.12 \%, \mathrm{TiO}_{2} 37.10 \%,(\mathrm{Nb}, \mathrm{Ta})_{2} \mathrm{O}_{5} 15.43 \%, \mathrm{SiO}_{2} 2.27 \%$, $\mathrm{H}_{2} \mathrm{O} \quad 0.87 \%$. The chemical analyses do not show strict coincidence with those of the ilmenorutile from Teshirogi, Fukushima Prefecture, but upon consideration of the results of other studies and the fact that ilmenorutile or strüverite is a mixture of crystal of mossite and rutile, this mineral may be determined as ilmenorutile. When compared with that from Teshirogi, the content of manganese is a little higher, so this may be called manganoilmenorutile. 